\title{
France plans marine research port at Brest
}

Declan Butler, Paris

Nazi Germany recognized the excellent strategic position and geography of the French port Brest, and installed its U-boat base there during the Second World War. Now France plans to spend FF39 million (\$5.4 million) building a scientific port there to support its extensive research fleet and oceanographic campaigns.

The French marine research agency, IFREMER, has the second largest research fleet in the world after the United States. With seven large research ships, two manned submarines that can dive to 6,000 metres, and a series of robotic and other seagoing facilities, the fleet is comparable to that of the United Kingdom.

Around half of the agency's 1,700-strong workforce is already based in or around Brest, which is also home to marine laboratories from several universities and the national basic research agency CNRS. The other large concentration is in Marseille, for Mediterranean-related research. Brest is also home to the French Institute for Polar Research and Technology.

But its working conditions are less than ideal, explains Joël Quérellou, director of the IFREMER centre in the city. Research vessels share the commercial port, and specialized support and research facilities are lacking. IFREMER's own laboratories are spread out over four sites.

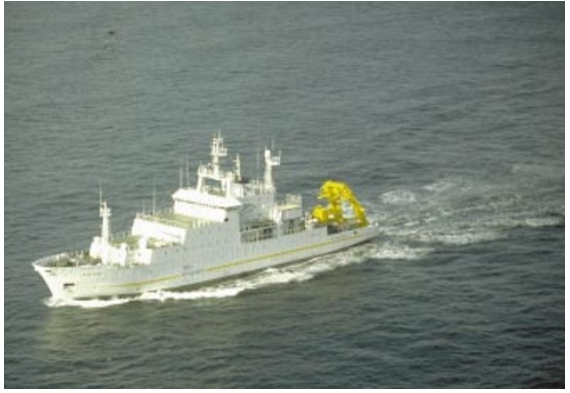

Splashing out: Atalante is part of the IFREMER fleet that may move to the new port at Brest.

The new plan, says Quérellou, who is the main architect of the project, will concentrate 200 support staff and facilities in a dedicated scientific port alongside the commercial port.

The infrastructure available at Brest's vast military port is better than that available at the trading port. But the option of locating the scientific port there has been discounted, mainly because security considerations could delay ocean research campaigns involving foreign scientists.

The money for the project is coming from regional and state funding, and has not been difficult to muster. The military arsenal is in decline, with job cuts of 350 this year reducing the workforce to 4,000 , and the government is keen to boost alternatives for growth in the region.
This week, the Océanopolis marine theme park reopens in the area, for example, after a FF250 million refurbishment. Its vast aquariums and displays, the outcome of a joint effort between the local scientific community and the centre, are expected to attract 600,000 visitors annually.

Quérellou says that in the past these local factors have been imperative, but he now intends to explore Brest's role in Europe's overall marine research. Not before time, says Pierre Papon, a former director of IFREMER. He argues that national initiatives can no longer afford to be pursued in isolation from their European context.

Although France, Britain and Germany have agreed to cooperate in the use of the 40 or so existing research vessels (see Nature 379, 576; 1996), and some ships have been built jointly - the Franco-Spanish Thalassa, and a smaller Franco-Italian ship, L'Europe, for example - there is a need for greater cooperation, such as in the planning of future needs for vessels.

A proposal to create a European maritime research agency (see Nature 392, 323; 1998) now seems unlikely to be realized, a lighter coordination being preferred by many European countries. This idea will be on the agenda of a European Union-sponsored conference, Ocean 2000, to be held in Hamburg, Germany in August.

\section{Transmutation of nuclear waste branded 'Trojan horse'}

\section{Colin Macilwain, Washington}

A technique for disposing of radioactive waste, under study by many nuclear powers, was last week branded "a Trojan horse for perpetrating nuclear power and hence the generation of more and more radioactive waste" by a respected environmental group based in Washington.

The technique, known as transmutation, is sometimes touted as a safe and costeffective way of disposing of nuclear waste. The governments of both France and the United States, for example, are currently weighing up proposals to expand their research into the field.

Transmutation would use neutrons from an accelerator or a nuclear reactor to break down radionuclides with long half-lives. Advocates say it could enable nuclear waste to become safe after a relatively short period of storage.

A team of US scientists at the Los Alamos National Laboratory in New Mexico has just prepared a 'technology roadmap' for the development of transmutation techniques.
This is now being considered by the US Department of Energy.

Meanwhile the French Atomic Energy Commission is refurbishing its PHENIX fast reactor at Marcoule, near Avignon, to enable it to conduct transmutation research before the reactor closes in 2004.

The commission is waiting for formal safety approval from the Direction de Sûreté des Installations Nucléaires before it can restart the reactor and allow the research programme to proceed.

But the Washington-based Institute for Energy and Environmental Research (IEER), led by physicist Arjun Makhijani, argues that the technology can never be made to work, as it cannot break down some of the most troublesome radionuclides, including strontium-90 and caesium-137. The IEER also says that transmutation would create new types of waste, "along with new proliferation risks and high costs".

Greg Van Tuyle, leader of the Accelerator Transmutation of Waste (ATW) group at Los Alamos, counters that the technology is "threatening to some groups primarily because it could help to restore the viability of nuclear energy at a time when it is becoming essential to addressing global climate change". He adds that transmutation "is the responsible approach" and would leave waste "in a form far less vulnerable to environmental release".

The IEER's scepticism about transmutation technology is widely shared, and the US Department of Energy has not allocated any money for its study in recent years. But Senator Pete Domenici (Republican, New Mexico), who chairs the appropriations subcommittee that funds the department, added \$9 million in the current fiscal year to pay the team at Los Alamos to prepare its transmutation roadmap.

A congressional official, who asked not to be identified, claims that the IEER report contains technical errors and "presumes the results of research that hasn't been done yet". The official says that Domenici "wants to avoid shutting down any possibility" for the safe disposal of nuclear waste. 